\title{
Documented exogenous progesterone hypersensitivity related to the use of combined oral contraceptive
}

\author{
Natalia Chamorro-Pareja, ${ }^{1}$ Ismael Carrillo-Martin, ${ }^{2}$ Daniela Andrea Haehn, ${ }^{3}$ \\ Alexei Gonzalez-Estrada® 1
}

'Division of Pulmonary, Allergy and Sleep Medicine, Department of Medicine, Mayo Clinic, Jacksonville, FL, USA

IInternal Medicine, Mayo Clinic's Campus in Florida, Jacksonville, FL, USA

${ }^{3}$ Anesthesia and Perioperative Medicine, Mayo Clinic, Jacksonville, FL, USA

\section{Correspondence to} Dr Alexei Gonzalez-Estrada, gonzalez.alexei@mayo.edu

Accepted 20 August 2019

Check for updates

(c) BMJ Publishing Group Limited 2019. No commercial re-use. See rights and permissions. Published by BMJ.

To cite: Chamorro-Pareja N, Carrillo-Martin I, Haehn DA, et al. BMJ Case Rep

2019:12:e230416

doi:10.1136/bcr-2019-

230416

\section{DESCRIPTION}

An 18-year-old woman with medical history of asthma reported a maculopapular non-pruritic rash on her neck and chest, throat closing sensation and chest tightness after 6 weeks of treatment with a combined oral contraceptive pill (OCP) ordered by her gynaecologist. The medication contained ferrous fumarate, ethinyl estradiol, and norethindrone acetate. Symptoms resolved within 3 days of discontinuation of the OCP and treatment with diphenhydramine.

At evaluation, physical exam ination was noncontributory. There was no evidence of eosinophilia on laboratory work up. Skin testing for the different components of the medication was performed with previous reported non-irritant concentrations ${ }^{1}$ (skin prick testing (SPT) and intradermal (ID)): progesterone $50 \mathrm{mg} / \mathrm{mL}$ (SPT undiluted; ID 1: 10 000, 1: 1000, 1: 100), estradiol $25 \mathrm{mg} / \mathrm{mL}$ (SPT undiluted; ID 1: 10 000, 1: 1000, 1: 100), ferrous sulfate $60 \mathrm{mg} / \mathrm{mL}$ (SPT undiluted; ID 1: 1000, 1: 100, 1: 10) and OCP dissolved in $1 \mathrm{~mL}$ (SPT undiluted; ID 1: 1000, 1: 100, 1: 10). Both progesterone and estradiol were diluted in olive oil based on a previous report by Foer $e t a l .{ }^{1}$ Ferrous sulfate and the OCP were diluted in human serum albumin (H SA) and filtered through a $0.22 \mu \mathrm{m}$ filter. Histamine diphosphate $1 \mathrm{mg} / \mathrm{mL}$ and $\mathrm{H}$ SA were used as positive and negative controls, respectively.

Skin testing was positive for progesterone (ID $(0.005 \mathrm{mg} / \mathrm{mL}))$, ferrous fumarate (ID $(6 \mathrm{mg} / \mathrm{mL}))$ and combined OCP (ID (pill dissolved in $1 \mathrm{~mL}$ ); figure 1). The patient was advised to avoid these medications and use estrogen-only contraceptive methods. The patient has been symptom-free since she suspended the combined OCP. Four months later, the patient was required to start iron replacement therapy due to anaemia. An open oral graded challenge to iron-containing multivitamin was performed without adverse reactions.

Progesterone hypersensitivity $(\mathrm{PH})$ is a rare condition that occurs in women of childbearing age. ${ }^{2}$ It has a diverse clinical presentation with symptoms including rash, urticaria with or without angioedema, wheezing, shortness of breath and anaphylaxis but can also present with erythema multiforme, fixed drug eruption and vesicular and bullous eruptions. ${ }^{3} \mathrm{PH}$ can be secondary to endogenous or exogenous sources of progesterone. Exogenous sources of progesterone include oral and implantable contraceptives, long-acting depot preparations, emergency contraception and intrauterine devices; they are an important and growing consideration in diagnosing $\mathrm{PH}$, especially with the increasing use in contraceptive methods and in vitro fertilisation (IVF). ${ }^{1}$

While it is more common to develop hypersensitivity reactions after IVF, considering the high levels of progesterone required, reactions to OCPs are more uncommon in view of the lower progesterone doses they contain. OCPs are usually found to be the primary source of exposure to progesterone in patients with endogenous $\mathrm{PH}$. In a report of $24 \mathrm{PH}$ cases, $58 \%$ of the patients presented symptoms after previous exposure to exogenous progesterone, and $25 \%$ were specifically secondary to OCP exposure. ${ }^{1}$

Diagnosing PH may be challenging due to its diverse clinical presentation. In this case, the diagnosis was based on the correlation of symptoms with the use of an OCP and was confirmed with skin testing. A positive skin test proofs the sensitivity to progesterone, but a negative result does not rule out the diagnosis. Immunological tests

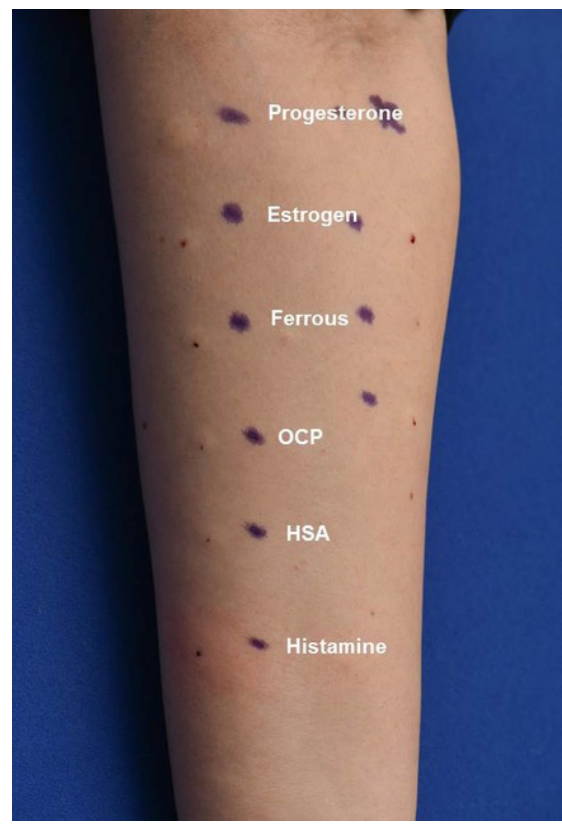

Figure 1 Testing for the different components of the medication. Positive progesterone testing (10 $\mathrm{mm} \times$ no flare), ferrous $(11.5 \times 17.5 \mathrm{~mm})$ and diluted OCP $(6 \times 12.5 \mathrm{~mm})$ with a positive histamine control $(10 \times 25 \mathrm{~mm})$. Negative oestrogen and negative control. HSA, human serum albumin; OCP, oral contraceptive pill. 
such as progesterone-specific IgE or basophil activation testing are possible diagnostic tests, which need to be studied further.

\section{Learning points}

- Exogenous sources of progesterone are an increasing cause of progesterone hypersensitivity.

- Oral contraceptive pills are usually found to be the primary source of exposure to progesterone in patients with exoogenous progesterone hypersensitivity.

- Diagnosing progesterone hypersensitivity may be challenging, but the combination of clinical history with a positive skin testing confirms the diagnosis.

Contributors NC-P contributed to conception and design, analysed and interpreted the data and prepared the manuscript. IC-M contributed to conception and design, analysed and interpreted the data and prepared and critically revised the manuscript. DAH analysed and interpreted the data and prepared the manuscript. AG-E contributed to conception and design, did supervision, analysed and interpreted the data and prepared and critically revised the manuscript.

Funding The authors have not declared a specific grant for this research from any funding agency in the public, commercial or not-for-profit sectors.

Competing interests None declared.

Patient consent for publication Obtained.

Provenance and peer review Not commissioned; externally peer reviewed.

\section{REFERENCES}

1 Foer D, Buchheit KM, Gargiulo AR, et al. Progestogen Hypersensitivity in 24 Cases: Diagnosis, Management, and Proposed Renaming and Classification. J Allergy Clin Immunol Pract 2016:4:723-9.

2 Nguyen T, Razzaque Ahmed A. Autoimmune progesterone dermatitis: Update and insights. Autoimmun Rev 2016:15:191-7.

3 Foer D, Buchheit KM. Progestogen Hypersensitivity: An Evidence-Based Approach to Diagnosis and Management in Clinical Practice. Immunol Allergy Clin North Am 2017;37:773-84.

Copyright 2019 BMJ Publishing Group. All rights reserved. For permission to reuse any of this content visit

https://www.bmj.com/company/products-services/rights-and-licensing/permissions/

BMJ Case Report Fellows may re-use this article for personal use and teaching without any further permission.

Become a Fellow of BMJ Case Reports today and you can:

- Submit as many cases as you like

- Enjoy fast sympathetic peer review and rapid publication of accepted articles

- Access all the published articles

Re-use any of the published material for personal use and teaching without further permission

Customer Service

If you have any further queries about your subscription, please contact our customer services team on +44 (0) 2071111105 or via email at support@bmj.com.

Visit casereports.bmj.com for more articles like this and to become a Fellow 